\title{
PHYTOREMEDIATION AS A PROSPECTIVE METHOD FOR REHABILITATION OF AREAS CONTAMINATED BY LONG-TERM SEWAGE SLUDGE STORAGE: GREEK EXPERIENCE
}

\author{
N. Suchkova \\ E. Darakas \\ J. Ganoulis \\ Aristotle University of Thessaloniki, Greece \\ $Y$. Vergeles \\ Kharkiv National Academy of Municipal Economy, Ukraine
}

\begin{abstract}
In this work the suitability of several plant species for phytoremediation under natural and artificially installed conditions was studied. Brassica napus, Medicago sativa, Zea mays, Triticum aestivum, and Hordeum vulgare were grown in pots with sewage sludge from Sindos Main WWTP in Thessaloniki and from Sindos Industrial WWTP in Thessaloniki, Greece.

The first series of experiments included comparing measurements of various parameters for the above mentioned plants and the sludge to those for control samples (the same plants growing in compost). It was shown that shoot growth was less reduced in $T$. aestivum and $H$. vulgare than in the other plant species studied. B. napus had lower germination tax, followed by $M$. sativa with the lowest germination tax. Generally $B$. napus, giving less biomass production than Z. mays and T. aestivum, is characterised by a higher ability to accumulate heavy metals like $\mathrm{Cd}, \mathrm{Cu}, \mathrm{Ni}, \mathrm{Pb}, \mathrm{Zn}, \mathrm{Cr}, \mathrm{As}$ and $\mathrm{Hg}$.

The second series of experiments included comparing measurements of various parameters of $B$. napus grown in sludge and treated each 7 days with metal solutions of $\mathrm{Ni}, \mathrm{Zn}$ and $\mathrm{Pb}$ containing $10^{-2} \mathrm{mg} / 1,10^{-4} \mathrm{mg} / 1,10^{-6} \mathrm{mg} / \mathrm{l}$ of each metal, to those for control plants treated with double distilled water. Results showed that shoot growth of $B$. napus were increased at treatments with lower concentrations of metals $\left(10^{-6} \mathrm{mg} / \mathrm{l}\right)$ and control (treatment with d-distilled water). At the same time uptake of metal ions was increased with the concentration of the solution, i.e. at higher concentrations $\left(10^{-2} \mathrm{mg} / \mathrm{l}\right)$. It is truly for $\mathrm{Pb}$ and $\mathrm{Zn}$, transfer coefficient $\mathrm{TC}$ of which (indicates a plant's potential to concentrate a metal) was quite high $15 \%$ and $7 \%$ correspondingly. It was noticed that $B$. napus has high ability to accumulate $\mathrm{Cr}$, from the other hand it did not accumulate $\mathrm{Ni}$ (at present case).
\end{abstract}

\section{KEYWORDS}

Phytoremediation, Soil contamination, Sewage sludge, Heavy metals, Germination. https://doi.org/10.15626/Eco-Tech.2010.090 


\section{INTRODUCTION}

Sewage sludge (also known as biosolids) is one of the final products of the treatment of sewage at wastewater treatment plant. It usually contains high levels $(10 \%$ to $>20 \%)$ of organic matter, and is rich in $\mathrm{N}$ and $\mathrm{P}$ that are essential for plant growth. Its application in agriculture and forestry, resulting in improved soil fertility, has been evaluated in many studies [6, 17]. Sludge also helps maintain soil structure, soil water holding ability, soil cation exchange capacity and soil biological activity [15]. On the other hand, sludge could be contaminated by heavy metals, hydrocarbons or other pollutants removed from the influent wastewater (usually in case, if WWTP treats industrial and mixed industrial and domestic wastewater), which can potentially cause soil pollution and toxic effect on plant growth. This is why in most cases wastewater sludge is not reused and is just left at the area of the WWTP. Thus, in Greece only $10 \%$ of produced sludge is reused in agriculture (for example, at Rethymno WWTP (Chania, Crete) [1, 2, $8,16,25])$, the rest $90 \%$ is directed to landfills' disposal [18]. Wastewater sludge could be used not only as a fertilizer; dried sludge could be used in the active cement industry as a fuel substitute. This is especially interesting for WWTPs in Athens and Thessaloniki, where land filling of the sludge can be seriously restricted due to the need for long transportation and the relatively poorer quality of the sludge in terms of fairly high heavy metal concentrations. By the moment the practice of sludge reuse in cement industry has been using in Athens. The next step is expected to be done for Thessalonikis' WWTPs, where there is no still provision for the reuse of the sludge.

The remediation of an area contaminated by sewage sludge storage represents a substantial financial burden for industry, the government and taxpayers. Traditional ex situ remediation efforts (e.g. excavation, burial and contaminant isolation) are not feasible for large-scale impacts and therefore alternative remediation strategies are necessary in cases where vast areas of land have been contaminated. Hyperaccumulator plants, such as Brassica napus ( $\mathrm{Cr}, \mathrm{Cu}, \mathrm{Hg}$, and $\mathrm{Pb})$, Medicago sativa $(\mathrm{Cr})$, Salix spp. $(\mathrm{Cr}, \mathrm{Zn}$, and $\mathrm{Pb})$, and Helianthus annuus $(\mathrm{Cr}, \mathrm{Pb}$, and $\mathrm{Zn})[19,20,22]$, are capable of concentrating trace metals in their harvestable biomass (phytoremediation), thereby offering a sustainable treatment option for metal-contaminated sites [24].

This study focuses on sludge issues at two WWTPs in Thessaloniki, Greece: Sindos Main WWTP and Sindos Industrial WWTP.

Thessaloniki is one of the most densely populated Greek cities with more than $1,000,000$ inhabitants. The city is surrounded by several residential communities, while an extended industrial area (Sindos) is located to the North West. Sindos WWTP (in operation since approximately 1983), the main WWTP for the city of Thessaloniki, receives daily around $150,000-160,000 \mathrm{~m}^{3}$ of wastewater from Thessaloniki's urban area via the central sewage system, as well as approximately $1,500 \mathrm{~m}^{3} /$ day of wastewater from areas with hauled waste. About 5-10\% of the total flow comes from industry. The plant also receives the greatest part of the local urban runoff, mainly composed of atmospheric deposition and traffic-related emissions deposited on the road 
surface. The treated wastewater is discharged into the Thermaikos Gulf via a channel. Sewage sludge (primary plus excess activated) is anaerobically digested, thickened, and dewatered with a polyelectrolyte addition in belt filter presses, giving a final product of about $23 \%$ in solids. Dewatered sludge is carried out to a specially designated part of the plant for storage [23]

Sindos Industrial WWTP (in operation since 1978), receives daily around 11,000$18,000 \mathrm{~m}^{3}$ of wastewater (including storm water) from oil refining, petrochemicals, fertilizers, non-ferrous metal smelting, iron and steel manufacturing, metal recovery facilities, electrolytic $\mathrm{MnO}_{2}$ production, scrap metal incineration, tyre production and lubricating oil recovery industries located in industrial area of Sindos [14]. The treated wastewater is discharged into the Thermaikos Gulf via a channel. The volume of sewage sludge (mixture of raw sludge from primary sedimentation tanks and activated sludge from aeration tanks) is about $200 \mathrm{t}$ /day with moisture content is approximately $90 \%$. It is anaerobically digested, thickened, and dewatered with a polyelectrolyte addition in 4 mechanical centrifuges, giving a final product of about $36 \mathrm{t} /$ day in solids with moisture content is of $17-18 \%$ in solids. Dewatered sludge is carried out to a specially designated part of the plant for storage. By the moment sewage sludge has been storing for 15-20 years approximately.

Taking into account the situation described above, phytoremediation is proposed as a method for rehabilitation of the sites contaminated with sewage sludge storage, application of which expected to be done during sludge reuse, for example, in cement industry or land reclamation. Thus, present work focused on the study of suitability of several plant species for phytoremediation under natural and artificially installed conditions. For this reason Brassica napus, Medicago sativa, Zea mays, Triticum aestivum and Hordeum vulgare were grown in pots with sludge taken from both the contaminated areas of the study, i.e. from Sindos Main WWTP and Sindos Industrial WWTP.

\section{MATERIALS AND METHODS}

\subsection{Studied area and material}

The first study (Experiment 1) took place in May and June 2008 with the use of dewatered sewage sludge from filter-presses from Sindos Main WWTP, Thessaloniki, Greece. Brassica napus, Medicago sativa, Triticum aestivum, Zea mays and Hordeum vulgare were grown in pots filled with contaminated media over a 30 day-period. Ten seeds of each plant species were sown directly into the substrate. The plants were watered regularly during their growing period. Garden compost was used as a control media.

The second experiment (Experiment 2) took place in autumn 2008 in a laboratory of Aristotle University of Thessaloniki. Dewatered sewage sludge from Sindos Industrial 
WWTP in Thessaloniki was used as an experimental material. Brassica napus was planted in pots approximately $15 \mathrm{~cm}$ wide and $18 \mathrm{~cm}$ deep (15 seeds per each pot) filled with the sludge over a 35 day-period. Sludge was treated each 7 days with solutions containing $10^{-6}, 10^{-4}, 10^{-2} \mathrm{mg} / \mathrm{l}$ of nickel $\left(\mathrm{Ni}^{+2}\right)$, zinc $\left(\mathrm{Zn}^{+2}\right)$, and lead $\left(\mathrm{Pb}^{+2}\right)$. Ni and $\mathrm{Pb}$ were applied as nitrate and $\mathrm{Zn}$ as sulfate. Control was maintained by treatment of the sludge by double distilled water regularly

during the growing period of plants.

Table 1. Characteristics of sewage sludge and compost (inlet data (day 0)) and (outlet data (day 30)) used in Experiment 1

\begin{tabular}{|c|c|c|c|c|c|}
\hline & $\begin{array}{l}\text { Compost } \\
\text { day } 0\end{array}$ & $\begin{array}{l}\text { Compost } \\
\text { day } 30\end{array}$ & $\begin{array}{l}\text { Sludge } \\
\text { day } 0\end{array}$ & $\begin{array}{l}\text { Sludge } \\
\text { day } 30\end{array}$ & Limit values ${ }^{a}$ \\
\hline Moisture content, $\%$ & 58.0 & 51.6 & 80.21 & 70.00 & \\
\hline $\mathrm{pH}$ & 7.3 & 5.8 & 8.1 & 6.6 & $5.5-8.5$ \\
\hline Organic matter, $\mathrm{mg} \mathrm{kg}^{-1}$ & 160.5 & 161 & 767 & 256.42 & \\
\hline $\mathrm{N}_{\text {tot }}, \mathrm{mg} \mathrm{kg}^{-1}$ & 12.0 & 54 & 20.25 & 55.00 & \\
\hline $\mathrm{C} / \mathrm{N}$ ratio & $13 / 1$ & $3 / 1$ & & & \\
\hline \multicolumn{6}{|l|}{ As, $\mathrm{mg} \mathrm{kg}^{-1} \mathrm{DW}$} \\
\hline $\mathrm{Cd}, \mathrm{mg} \mathrm{kg}^{-1} \mathrm{DW}$ & 1.0 & 0 & 2 & 1 & $20-40$ \\
\hline $\mathrm{Cr}, \mathrm{mg} \mathrm{kg}^{-1} \mathrm{DW}$ & 3.0 & 2.8 & 87 & 61 & 500 \\
\hline $\mathrm{Cu}, \mathrm{mg} \mathrm{kg}^{-1} \mathrm{DW}$ & 43.0 & 14 & 314 & 200 & $1,000-1,750$ \\
\hline \multicolumn{6}{|l|}{$\mathrm{Hg}, \mathrm{mg} \mathrm{kg}^{-1} \mathrm{DW}$} \\
\hline $\mathrm{Ni}, \mathrm{mg} \mathrm{kg}^{-1} \mathrm{DW}$ & 0 & 0 & 83 & 42 & $300-400$ \\
\hline $\mathrm{Pb}, \mathrm{mg} \mathrm{kg}^{-1} \mathrm{DW}$ & 4.0 & 6.2 & 79 & 59 & $750-1,200$ \\
\hline $\mathrm{Zn}, \mathrm{mg} \mathrm{kg}^{-1} \mathrm{DW}$ & 42.0 & 27 & 1,581 & 791 & $2,500-4,000$ \\
\hline
\end{tabular}

As, Hg were not determined.

a $86 / 278 /$ EEC Council Directive on the protection of the environment, and in particular of the soil, when sewage sludge is used in agriculture 


\subsection{Analytical methods for sample pretreatment}

The chemical analyses were conducted using Standard Methods [21]. In the Experiment 1 sludge/compost samples were taken on days 0, 18 and 30 (see Table 1), and in the Experiment 2 sludge samples were taken on days 0, 20 and 35 (see Table 2), while the plants were growing. The total organic matter and nutrients content in the sludge from Experiment 1 and Experiment 2 were much more than in the control compost used. This sludge contained heavy metals within the permissible limit values [4], and only $\mathrm{Zn}$ content was close to the limits. Meanwhile, sludge from Experiment 2 (Industrial WWTP) was contaminated with $\mathrm{Cr}$, the levels of $\mathrm{Ni}$ and $\mathrm{Zn}$ are near to limit values. The compost from Experiment 1 did not contain any valuable heavy metal concentrations.

Sludge/compost moisture content was determined using Standard ISO 11465 [10] by gravimetric method based on the weight loss of wet sludge/compost sample at $105^{\circ} \mathrm{C}$; $\mathrm{pH}$ was measured potentiometrically in the supernatant suspension of a 1:5 sludge/compost: distilled water (v/v) mixture according to the ISO 10390 [11]; organic matter content was measured on a TOC-5000 (Shimadzu) analyser by ISO 10694 [12, 26]; total nitrogen was determined spectrophotometrically, using a WinLab Data Line photometer (Windaus Labortechnik). The determination of heavy metals in both sludge/compost and the plants samples was carried out by AAS, with flame and graphite furnace modes. A PerkinElmer 503 Atomic Absorption Spectrophotometer was used coupled with a THGA-800 graphite furnace controller. On day 30 of Experiment 1 and on days 20 and 35 of Experiment 2, the plants were carefully uprooted, washed thoroughly with water and rinsed with distilled water in order to remove any sludge particles from the substrate. After washing the roots and shoots were separated (only in Experiment 1) and left to dry at room temperature until their weight was constant. Then they were dried in an oven at $65{ }^{\circ} \mathrm{C}$ for $24 \mathrm{~h}$ and further crushed. The wet digestion of organic matrix sampled (plants, sludge, and compost) by use of concentrated and dissolved $\mathrm{HNO}_{3}$ as the most common procedure was used for sample pretreatment [3]. An accurately weighed portion of each plant, sludge or compost sample $(0.2 \pm 0.0001 \mathrm{~g}$ 
Table 2. Characteristics of sewage sludge and compost (inlet data (day 0)) and (outlet data (day 20 and 35)) used in Experiment 2

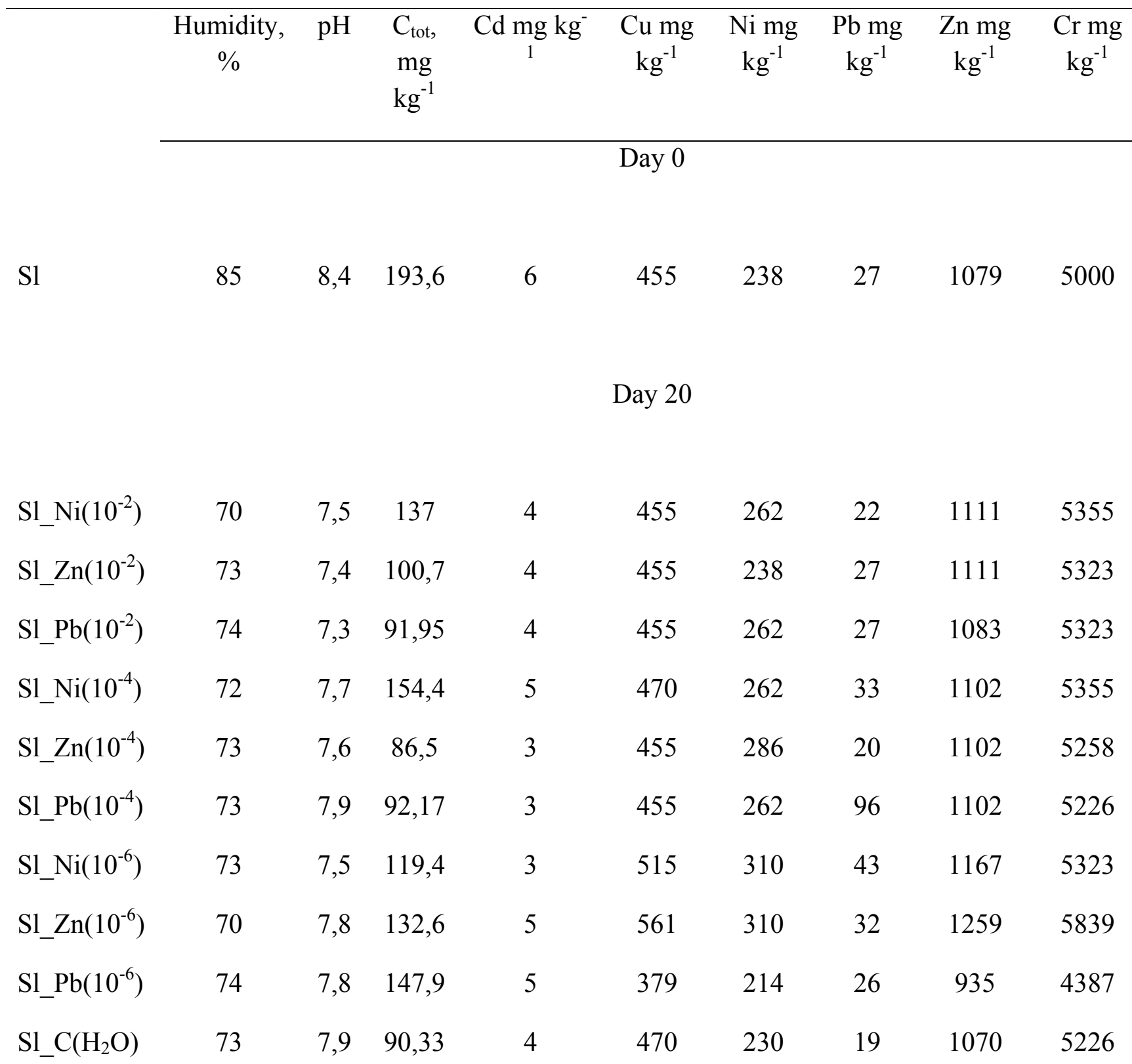

Day 35

$\begin{array}{llllllll}\text { S1_Ni }\left(10^{-2}\right) & 66 & 4 & 470 & 214 & 24 & 1157 & 5516 \\ \text { S1_Zn }\left(10^{-2}\right) & 60 & 4 & 470 & 238 & 27 & 1040 & 5613\end{array}$




\begin{tabular}{llllllll}
$\mathrm{S} 1 \_\mathrm{Pb}\left(10^{-2}\right)$ & 63 & 4 & 455 & 238 & 24 & 1134 & 5403 \\
$\mathrm{~S} 1 \_\mathrm{Ni}\left(10^{-4}\right)$ & 61 & 4 & 455 & 200 & 20 & 1102 & 5323 \\
$\mathrm{~S} 1 \_\mathrm{Zn}\left(10^{-4}\right)$ & 61 & 4 & 455 & 238 & 20 & 1000 & 5484 \\
$\mathrm{~S} 1 \_\mathrm{Pb}\left(10^{-4}\right)$ & 61 & 4 & 439 & 238 & 24 & 1065 & 5097 \\
$\mathrm{~S} 1 \_\mathrm{Ni}\left(10^{-6}\right)$ & 62 & 4 & 485 & 190 & 19 & 1120 & 5161 \\
$\mathrm{~S} 1 \_\mathrm{Zn}\left(10^{-6}\right)$ & 62 & 4 & 485 & 190 & 21 & 980 & 5242 \\
$\mathrm{~S} 1 \_\mathrm{Pb}\left(10^{-6}\right)$ & 63 & 5 & 485 & 262 & 22 & 1157 & 5387 \\
$\mathrm{~S} 1 \_\mathrm{C}\left(\mathrm{H}_{2} \mathrm{O}\right)$ & 72 & 4 & 485 & 220 & 17 & 1000 & 5484 \\
\hline
\end{tabular}

$\mathrm{pH}$, organic matter $\mathrm{C}_{\text {tot }}$ were not determined on day 35 of the experiment

Nomenclature: $\mathrm{Sl}$ - sludge; $10^{-2}, 10^{-4}, 10^{-6}$ - sludge treatment with $\mathrm{Ni}, \mathrm{Zn}$ and $\mathrm{Pb}$ containing 0,01 ; 0,$0001 ; 0,000001 \mathrm{mg} 1$ of metal respectively.

dry weight) was placed in a Teflon beaker. About $20 \mathrm{ml}$ of concentrated $\mathrm{HNO}_{3}$ was added to each beaker and the mixture was covered with a lid. This was then left at room temperature for $24 \mathrm{~h}$. Afterwards it was heated to near dryness on a sand bath, subsequently dissolved in $20 \mathrm{ml} 1+1 \mathrm{HNO}_{3}$ and was heated on a sand bath for exactly $30 \mathrm{~min}$. The residue was diluted to $200 \mathrm{ml}$ with d-distilled water (the beakers were also washed twice with d-distilled water), and the final solutions were analyzed for determining concentrations of metals $-\mathrm{Cd}, \mathrm{Cu}, \mathrm{Ni}, \mathrm{Pb}, \mathrm{Zn}$, and $\mathrm{Cr}$. In addition, on the $30^{\text {th }}$ and $35^{\text {th }}$ days of the two experiments correspondingly the dry mass of plants and the biometric parameters (germination tax, stem length and number of leaves) were measured (see Table 3, 4). Dry mass was established after drying the plant material in an oven at $65{ }^{\circ} \mathrm{C}$ for $24 \mathrm{~h} \mathrm{[13].}$ 
Table 3. Dry mass and biometric characteristics (mean, $n=10)$ of selected plants grown at contaminated media on day 30 in Experiment 1

\begin{tabular}{|c|c|c|c|c|}
\hline Substrate & $\begin{array}{c}\text { Germination } \\
\operatorname{tax}(\%)\end{array}$ & $\begin{array}{l}\text { Stem length } \\
(\mathrm{cm})\end{array}$ & Number of leaves & Dry mass $^{\mathbf{a}}$ of plants $(\mathrm{g})$ \\
\hline
\end{tabular}

Brassica napus

$\begin{array}{lllll}\text { Sewage sludge } & 100 & 5 & 2 & 0.382 \\ \text { Compost (control) } & 100 & 8 & 5 & 0.282\end{array}$

Zea maize

$\begin{array}{lcccc}\text { Sewage sludge } & 80 & 41 & 6 & 2.266 \\ \text { Compost (control) } & 100 & 39 & 4 & 0.615\end{array}$

Triticum aestivum

$\begin{array}{lllll}\text { Sewage sludge } & 100 & 25 & 2 & 0.236 \\ \text { Compost (control) } & 100 & 23 & 2 & 0.200\end{array}$

Hordeum vulgare

$\begin{array}{lcccc}\text { Sewage sludge } & 100 & 18 & 1 & 0.278 \\ \text { Compost (control) } & 100 & 17 & 1 & 0.199\end{array}$

\footnotetext{
${ }^{\mathbf{a}}$ Number of plants sampled for dry mass measurements differs from plant to plant and substrate $(B$. napus in sludge and compost $n=5 ; Z$. mays in sludge $n=3, Z$. mays in compost $n=1 ; T$. aestivum in sludge and compost $\mathrm{n}=5 ; H$. vulgare in sludge and compost $\mathrm{n}=5$ ).
} 
Table 4. Dry mass and biometric characteristics of B. napus plants grown at contaminated media on days 20 and 35 in Experiment 2

\begin{tabular}{|c|c|c|c|c|c|}
\hline & $\begin{array}{l}\text { Stem length } \\
(\mathrm{cm})\end{array}$ & $\begin{array}{l}\text { Leaf area } \\
\left(\mathrm{cm}^{2}\right)\end{array}$ & $\begin{array}{c}\text { Number of } \\
\text { leaves }\end{array}$ & $\begin{array}{c}\text { Germination tax } \\
(\%)\end{array}$ & $\begin{array}{l}\text { Dry mass }^{\mathrm{a}} \\
(\mathrm{g})\end{array}$ \\
\hline & & & Day 20 & & \\
\hline P_Sl_Ni $\left(10^{-2}\right)$ & 2,25 & 0,21 & 2 & 13,3 & \\
\hline P_Sl_Zn $\left(10^{-2}\right)$ & 4,33 & 0,28 & 2 & 20 & \\
\hline P_Sl_Pb $\left(10^{-2}\right)$ & 6,83 & 0,66 & 2 & 46,7 & \\
\hline P_Sl_Ni $\left(10^{-4}\right)$ & 3 & 0,2 & 3 & 40 & \\
\hline P_Sl_Zn $\left(10^{-4}\right)$ & 2,75 & 0,09 & 2 & 13,3 & \\
\hline P_Sl_Pb $\left(10^{-4}\right)$ & 5 & 0,12 & 3 & 6,7 & \\
\hline P_Sl_Ni $\left(10^{-6}\right)$ & 5,5 & 0,5 & 3 & 73,3 & 0,027 \\
\hline P_Sl_Zn $\left(10^{-6}\right)$ & 7 & 0,91 & 3 & 66,7 & 0,033 \\
\hline P_Sl_Pb $\left(10^{-6}\right)$ & 4,5 & 0,35 & 4 & 26,7 & \\
\hline \multirow[t]{2}{*}{ P_Sl_C $\left(\mathrm{H}_{2} \mathrm{O}\right)$} & 6,33 & 0,28 & 3 & 73,3 & 0,02 \\
\hline & & & Day 35 & & \\
\hline P_Sl_Ni $\left(10^{-2}\right)$ & 4,5 & 0,3 & 4 & 13,3 & 0,07 \\
\hline P_Sl_Zn $\left(10^{-2}\right)$ & 6,3 & 0,48 & 3 & 20 & 0,35 \\
\hline P_Sl_Pb $\left(10^{-2}\right)$ & 10 & 0,76 & 3 & 46,7 & 0,4 \\
\hline P_Sl_Ni $\left(10^{-4}\right)$ & 7,33 & 0,4 & 4 & 40 & 0,47 \\
\hline P_Sl_Zn $\left(10^{-4}\right)$ & 4 & 0,18 & 3 & 13,3 & 0,015 \\
\hline P_Sl_Pb $\left(10^{-4}\right)$ & 7 & 0,25 & 3 & 6,7 & 0,004 \\
\hline P_Sl_Ni $\left(10^{-6}\right)$ & 8,5 & 1,1 & 4 & 73,3 & 0,25 \\
\hline P_Sl_Zn $\left(10^{-6}\right)$ & 9 & 1,2 & 4 & 66,7 & 0,18 \\
\hline
\end{tabular}




\begin{tabular}{lccccc}
\hline P_Sl_Pb(10 $\left(10^{-6}\right)$ & 6,4 & 0,6 & 6 & 26,7 & 0,05 \\
P_Sl_C( $\left.\mathrm{H}_{2} \mathrm{O}\right)$ & 9,3 & 0,5 & 5 & 73,3 & 0,33
\end{tabular}

\section{RESULTS}

\subsection{Growth and heavy metal uptake}

\subsubsection{Experiment 1}

The seed germination rates of five plant species in contaminated media compared to control is shown in Table 3. Germination rate of B. napus, Z. mays, T. aestivum and $H$. vulgare in both the control substrates (compost) and in the sludge in the Experiment 1 was high, about $100 \%$, while the growth of $M$. sativa was close to $0 \%$. In general, it was noticed the higher accumulation of all the metals in root parts of the plants. Thus, $T$. aestivum showed good results in accumulation (in $\mathrm{mg} \mathrm{kg}^{-1} \mathrm{DW}$ ) of $\mathrm{Cu}$ (71) and $\mathrm{Ni}$ (42) in comparison to the control plants, while Z. mays had a better accumulation of (in $\mathrm{mg}$ $\left.\mathrm{kg}^{-1} \mathrm{DW}\right) \mathrm{Pb}(23)$ and $\mathrm{Zn}$ (325) (see Figures 1-3).

\subsubsection{Experiment 2}

The seed germination rates of $B$. napus in contaminated media compared to control is shown in Table 4. In the Experiment 2, where plants' metal treatment had place, it is obvious that germination tax increases in the pots with plants treated with lower concentration of metals $\left(10^{-6} \mathrm{mg} / \mathrm{l}\right)$ and control (treated with d-distilled $\left.\mathrm{H}_{2} \mathrm{O}\right)$. This is truly for $\mathrm{Zn}$ and $\mathrm{Ni}$, where germination tax of $\mathrm{B}$ napus reached $70 \%$ comparing to $13 \%$ and $20 \%$ at concentration $10^{-2} \mathrm{mg} / \mathrm{l}$ of $\mathrm{Ni}$ and $\mathrm{Zn}$ correspondingly. However, $\mathrm{Pb}$ had back effect on the germination rate, which is higher in plants treated with higher concentrations $\left(10^{-2} \mathrm{mg} / \mathrm{l}\right)$ and reached $50 \%$ comparing to germination tax of $7 \%$ and $27 \%$ at concentrations $10^{-4}$ and $10^{-6} \mathrm{mg} / \mathrm{l}$ of $\mathrm{Pb}$.

B. napus stem length was affected by heavy metal application. Plants grown up at low $\mathrm{Zn}$ and Ni concentrations had increase in average stem length in comparison to the plants grown up at high concentrations of the same metals, whereas $\mathrm{Pb}$ increased the growth rate at its concentration $10^{-2} \mathrm{mg} / \mathrm{l}$.

Heavy metals uptake was different depending on the element application as well as on their concentration. In general the uptake of $\mathrm{Zn}$ at higher concentrations of three investigated metals was higher. Thus, $\mathrm{Zn}\left(74 \mathrm{mg} \mathrm{kg}^{-1} \mathrm{DW}\right),\left(65 \mathrm{mg} \mathrm{kg}^{-1} \mathrm{DW}\right)$ and (144 $\left.\mathrm{mg} \mathrm{kg}{ }^{-1} \mathrm{DW}\right)$ at $\mathrm{Zn}, \mathrm{Pb}$ and $\mathrm{Ni}$ treatment with concentration $10^{-2} \mathrm{mg} / \mathrm{l}$ of metal correspondingly, whereas Zn (69 $\left.\mathrm{mg} \mathrm{kg}^{-1} \mathrm{DW}\right),\left(93 \mathrm{mg} \mathrm{kg}^{-1} \mathrm{DW}\right)$ and $\left(0 \mathrm{mg} \mathrm{kg}^{-1} \mathrm{DW}\right)$ at $\mathrm{Zn}, \mathrm{Pb}$ and $\mathrm{Ni}$ treatment with $10^{-6} \mathrm{mg} / \mathrm{l}$ correspondingly. The same situation was observed with $\mathrm{Pb}$, which uptake increased with the concentration of the $\mathrm{Pb}$ solution 
applied to the sludge. Thus, $\mathrm{Pb}\left(6 \mathrm{mg} \mathrm{kg}^{-1} \mathrm{DW}\right)$ at $10^{-2} \mathrm{mg} / \mathrm{l}$ of $\mathrm{Pb}$, whereas $\mathrm{Pb}(0 \mathrm{mg}$ $\left.\mathrm{kg}^{-1} \mathrm{DW}\right)$ at $10^{-6} \mathrm{mg} / \mathrm{l}$ of $\mathrm{Pb}$. B. napus did not accumulate $\mathrm{Ni}$.

B. napus showed good accumulation of $\mathrm{Cr}$ in all metals' treatment and it was: $\mathrm{Cr}$ (194 $\left.\mathrm{mg} \mathrm{kg}{ }^{-1} \mathrm{DW}\right),\left(145 \mathrm{mg} \mathrm{kg}^{-1} \mathrm{DW}\right)$ and $\left(565 \mathrm{mg} \mathrm{kg}^{-1} \mathrm{DW}\right)$ at treatment, containing $10^{-2}$ $\mathrm{mg} / \mathrm{l}$ of $\mathrm{Zn}, \mathrm{Pb}$ and Ni correspondingly; $\mathrm{Cr}$ (177 $\left.\mathrm{mg} \mathrm{kg}^{-1} \mathrm{DW}\right),\left(323 \mathrm{mg} \mathrm{kg}^{-1} \mathrm{DW}\right)$, and (81 $\mathrm{mg} \mathrm{kg}^{-1} \mathrm{DW}$ ) at treatment, containing $10^{-6} \mathrm{mg} / \mathrm{l}$ of $\mathrm{Zn}, \mathrm{Pb}$ and $\mathrm{Ni}$ correspondingly.

\section{DISCUSSION}

Methods for evaluating the presence of heavy metals are based on the amount of the element absorbed by the plant in correlation with growth and biomass productivity. These relationships are dependent on characteristics of the soil, the sludge, and the species used.

In order to estimate the transfer of heavy metals from the sludge to the plants several traditional parameters were used [15, 24]: transfer coefficient (TC; i.e. the percentage of metals transferred from the sludge to the shoots (leaves)), which indicates a plant's potential to concentrate a metal and translocation factor (TF; i.e. the ratio of metal concentration in shoot tissue to metal concentration in root tissue), which estimates the translocation efficiency of a plant; TF for a hyperaccumulators is typically $>1$. 
Table 5. TC and TF of heavy metals for different plant species from both experiments

\begin{tabular}{|c|c|c|c|c|}
\hline & \multicolumn{2}{|c|}{ Experiment 1} & & \multirow{2}{*}{$\begin{array}{c}\text { Experiment } 2 \\
\mathrm{TC}(\%)\end{array}$} \\
\hline & $\mathrm{TC}(\%)$ & $\mathrm{TF}$ & & \\
\hline $\mathrm{Cu}$ & & & $\mathrm{Cu}$ in B. napus & \\
\hline Brassica napus & 9.2 & & P_Sl_Ni $\left(10^{-4}\right)$ & 13.4 \\
\hline \multicolumn{5}{|l|}{ Medicago sativa } \\
\hline Zea mays & 13.7 & 1 & & \\
\hline Triticum aestivum & 13.7 & 0.6 & & \\
\hline Hordeum vulgare & 9.2 & & & \\
\hline $\mathrm{Pb}$ & & & $\mathrm{Pb}$ in $B$. napus & \\
\hline Brassica napus & 8.9 & & P_Sl_Pb $\left(10^{-2}\right)$ & 25 \\
\hline Medicago sativa & 0 & & P_Sl_Ni $\left(10^{-4}\right)$ & 5 \\
\hline Zea mays & 3.8 & 0.1 & P_Sl_Ni $\left(10^{-6}\right)$ & 26.3 \\
\hline Triticum aestivum & 3.8 & 0.2 & P_Sl_Zn $\left(10^{-6}\right)$ & 9.5 \\
\hline \multirow[t]{2}{*}{ Hordeum vulgare } & 3.8 & & P_Sl_Pb $\left(10^{-6}\right)$ & 0 \\
\hline & & & P_Sl_C $\left(\mathrm{H}_{2} \mathrm{O}\right)$ & 41.2 \\
\hline $\mathrm{Zn}$ & & & $\mathrm{Zn}$ in B. napus & \\
\hline Brassica napus & 3 & & P_Sl_Zn $\left(10^{-2}\right)$ & 7.1 \\
\hline Medicago sativa & 0 & & P_Sl_Pb $\left(10^{-2}\right)$ & 5.7 \\
\hline Zea mays & 10.8 & 0.5 & P_Sl_Ni $\left(10^{-4}\right)$ & 13.1 \\
\hline Triticum aestivum & 3.2 & 0.2 & P_Sl_Ni $\left(10^{-6}\right)$ & 0 \\
\hline \multirow[t]{3}{*}{ Hordeum vulgare } & 3.7 & & P_Sl_Zn $\left(10^{-6}\right)$ & 7 \\
\hline & & & P_Sl_Pb $\left(10^{-6}\right)$ & 8 \\
\hline & & & P_Sl_C $\left(\mathrm{H}_{2} \mathrm{O}\right)$ & 9.3 \\
\hline
\end{tabular}


$\mathrm{Cr}$

Brassica napus

Medicago sativa

Zea mays

Triticum aestivum

Hordeum vulgare
4.6
$\mathrm{Cr}$ in B. napus

$$
\begin{array}{lc}
\text { P_Sl_Zn }\left(10^{-2}\right) & 3.5 \\
\text { P_S1_Pb }\left(10^{-2}\right) & 2.7 \\
\text { P_Sl_Ni }\left(10^{-4}\right) & 10.6 \\
\text { P_S1_Ni }\left(10^{-6}\right) & 1.6 \\
\text { P_Sl_Zn }\left(10^{-6}\right) & 3.4 \\
\text { P_S1_Pb }\left(10^{-6}\right) & 6 \\
\text { P_Sl_C }\left(\mathrm{H}_{2} \mathrm{O}\right) & 5
\end{array}
$$

The TC of metals was different depending on the plant species as well as on the element analyzed (see Table 5).

In both experiments Brassica napus had quite high TC values in comparison to other species, followed by Zea mays, Triticum aestivum, and Hordeum vulgare (for the Experiment 1). In the first experiment $\mathrm{Cu}$ was the most transferable, with $\mathrm{TC}$ values of between $9 \%$ and $13 \%$, followed by $\mathrm{Cr}, \mathrm{Zn}$, and $\mathrm{Pb}$, while in the second experiment $\mathrm{Pb}$ was the most transferable.

The distribution of the metals within the shoots and roots was different: $\mathrm{Cu}, \mathrm{Zn}$ and $\mathrm{Cr}$ were found in the shoots, while the greatest amount of $\mathrm{Pb}$ was observed in the roots (the lowest TF).

In the Experiment 2 in general at all treatments $\left(10^{-2}-10^{-6} \mathrm{mg} / \mathrm{l}\right)$ B. napus actively accumulated $\mathrm{Pb}, \mathrm{Zn}$ and $\mathrm{Cr}$. The highest $\mathrm{TC}$ values were found for the $\mathrm{Pb}$. So, $\mathrm{Pb}$, with average TC value of $15 \%$, was the most transferable, followed by $\mathrm{Zn}$, with average TC value of $7 \%$, and $\mathrm{Cr}$, with average $\mathrm{TC}$ value of $4 \% . \mathrm{Cd}$ and $\mathrm{Cu}$ were the least transferable. In the present research Ni was not accumulated by B. napus.

What is more, $\mathrm{Pb}$ accumulated in higher extent at treatment with $\mathrm{Pb}$ in higher concentration $\left(10^{-2} \mathrm{mg} / \mathrm{l}\right)(\mathrm{TC}=25 \%)$, whereas at treatment with $\mathrm{Pb}$ in low concentration $\left(10^{-6} \mathrm{mg} / \mathrm{l}\right)$ accumulation was negligible $(\mathrm{TC}=0)$.

Present research was carried out over a 35 day period. It was noticed that during the first 20 days of active sludge treatment with heavy metals, their concentrations in the substrate increased in comparison with the initial concentrations (day 0), however, on day 35 their concentrations were found less than on day 0 (see Figures 4-7). At the same time concentrations of heavy metals in B. napus plants on day 35 in comparison with on day 20 were higher. This could be explained by following: during the first 20 days of experiment there was no enough biomass produced by plants and able to accumulate metals. With the plants growth and development (closer to day 35) metals concentration in substrate started to decrease due to their accumulation in the plants. The concentration of metals in substrate treated with d-distilled water (control) slowly decreased from day 0 to day 35, what is shown in Figure 7. 
In both experiments the sludge treatment with heavy metals did not cause phytotoxicity symptoms in the plants. Chaney [7] and Environment Canada [9] have indicated the range of toxicity levels for some metals in leaf tissues for various species to be as follows: $\mathrm{Cd}, 5$ to $700 ; \mathrm{Cu}, 25$ to $40 ; \mathrm{Ni}, 50$ to $100 ; \mathrm{Zn}, 500$ to $1500 ; \mathrm{Pb}, 30$ to $300 \mathrm{mg}$ $\mathrm{kg}^{-1} \mathrm{DW}$. The maximum plants (shoot and roots) metal concentrations recorded in the experiment were below these levels. Moreover, there was not noticed any chlorosis or necrosis effects on the plants.

\section{CONCLUSIONS}

We intended on searching the most suitable plants for phytoremediation in cases of Sindos Main WWTP and Sindos Industrial WWTP in Thessaloniki, Greece, application of which expected to be done after the process of sludge reuse will begin. Using five plant species both the capacity of the plants to accumulate metals in their parts and the plants' tolerance to metals (especially in the Experiment 2) were studied. It can be concluded that sludge, rich in organic matter, is a good medium for all plant species, giving a high biomass production.

From the both experiments it could be concluded that Brassica napus had a good capacity to tolerate and accumulate metals. None of the plant species showed any symptoms of toxicity due to the absorption of heavy metals.

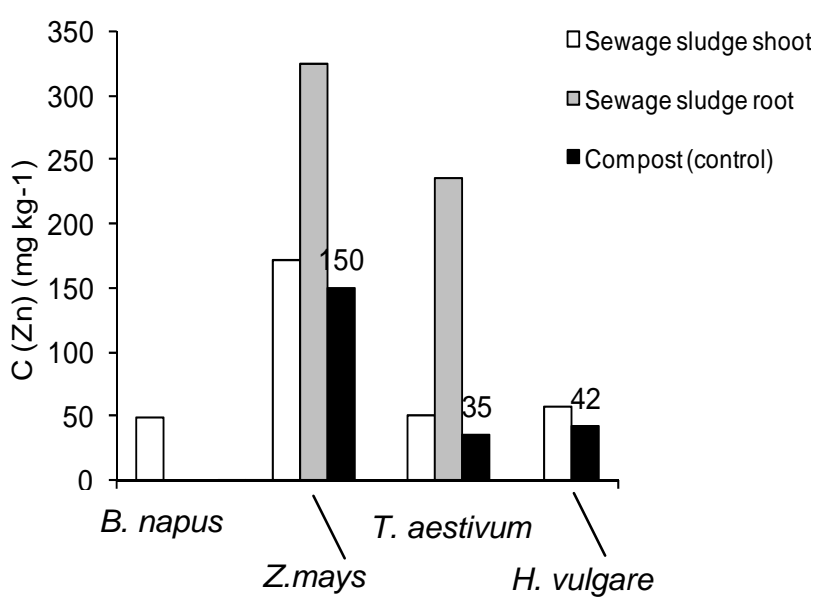

Figure 1. Zinc $\left(\mathrm{mg} \mathrm{kg}^{-1}\right)$ concentration in plant species grown during 30 days in sewage sludge in sewage sludge

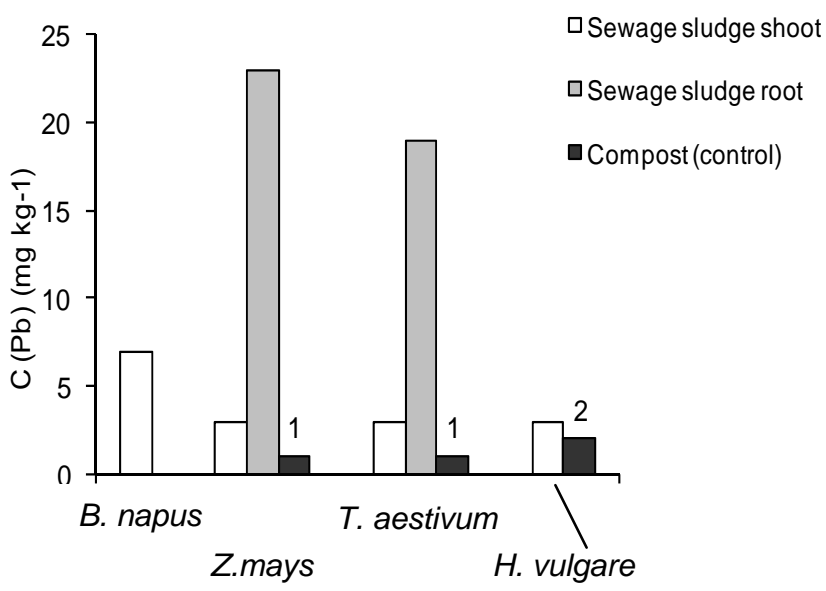

Figure 2. Lead (mg kg-1) oncentration in plant species grown during 30 days 


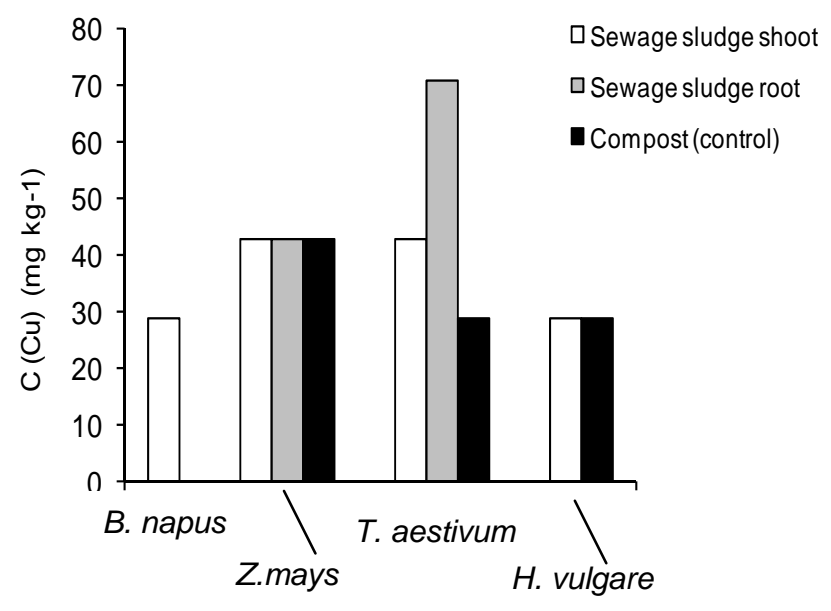

Figure 3. Copper $\left(\mathrm{mg} \mathrm{kg}^{-1}\right)$ concentration in plant species grown during 30 days in sewage sludge
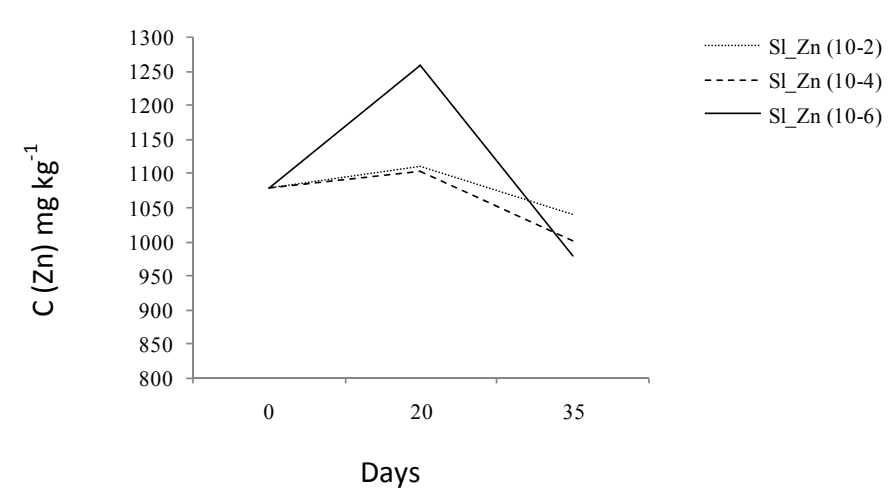

Figure 5. Zinc $\left(\mathrm{mg} \mathrm{kg}^{-1}\right)$ concentration in sludge treated with zinc in different concentrations within experimental days

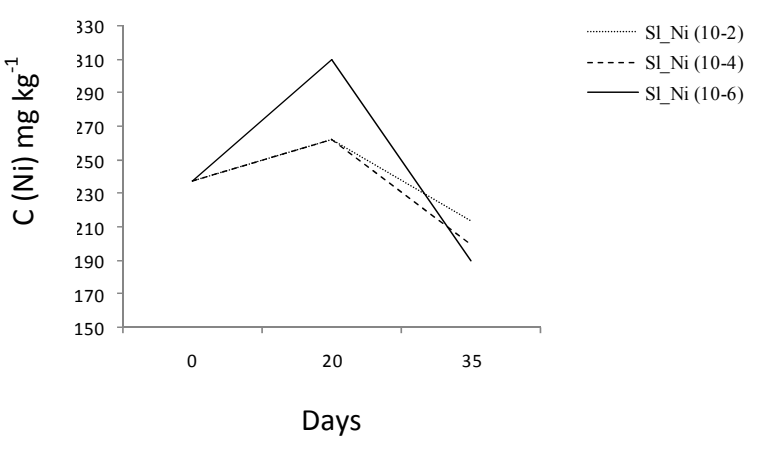

Figure 4. Nickel ( $\left.\mathrm{mg} \mathrm{kg}^{-1}\right)$ concentration in sludge treated with nickel in different concentrations within experimental days

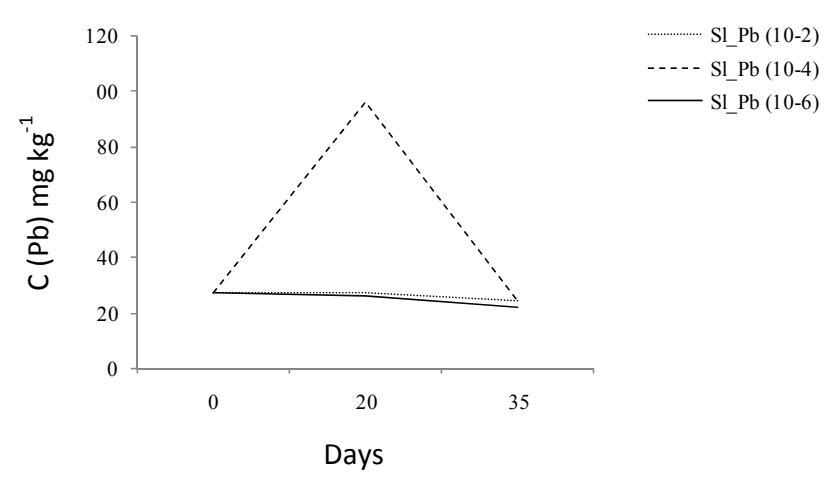

Figure 6. Lead $\left(\mathrm{mg} \mathrm{kg}^{-1}\right)$ concentration in sludge treated with lead in different concentration within experimental days

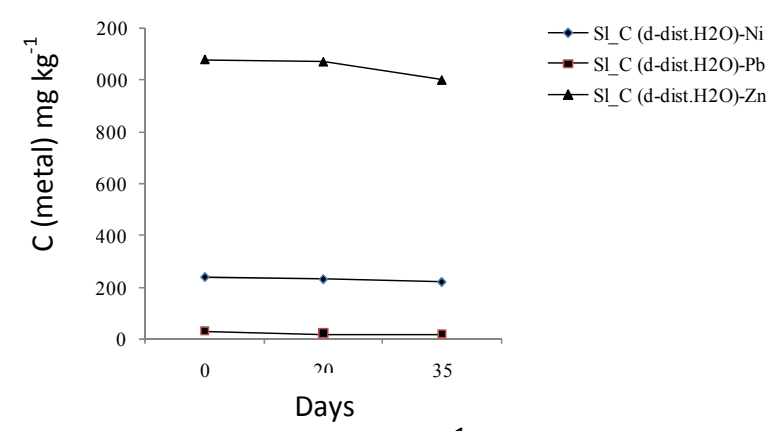

Figure 7. Metals $\left(\mathrm{mg} \mathrm{kg}^{-1}\right)$ concentration in sludge treated with $\mathrm{H}_{2} \mathrm{O}$ within experimental days 
In the Experiment 1 it was shown that the highest concentration of metals is in the plants, grown in sludge (in comparison to the control compost) and in their root parts (in comparison to their shoot parts). Thus, huge amounts of $\mathrm{Pb}$ were found in the roots of the plants. The accumulation of metals in roots would in effect immobilize the metals for a certain period of time, therefore reducing risks of contamination by inhibiting the circulation of these pollutants in the environment. This is important for perennial plants. On the other hand, for B. napus, Z. mays and T. aestivum, which are the annual plants, metal accumulation in the leaf area is referable. In the case of their use for phytoremediation the utilization of leaves rich in heavy metals has to be organized at the end of the harvest season.

In the Experiment 2, where sludge with the plants were treated with heavy metals solutions, containing $10^{-6}, 10^{-4}, 10^{-2} \mathrm{mg} / \mathrm{l}$ of nickel $\left(\mathrm{Ni}^{+2}\right)$, zinc $\left(\mathrm{Zn}^{+2}\right)$, and lead $\left(\mathrm{Pb}^{+2}\right)$, was found the following: if shoot growth of $B$. napus were increased at treatments with lower concentrations of metals $\left(10^{-6} \mathrm{mg} / \mathrm{l}\right)$ and control (treatment with d-distilled water), the uptake of metal ions was increased at treatments with higher concentrations $\left(10^{-2}\right.$ $\mathrm{mg} / \mathrm{l})$.

It was determined that the order of transferability of the metallic ions was as follows: $\mathrm{Pb}$ and $\mathrm{Zn}$ with transfer coefficient TC $15 \%$ and $7 \%$ being the most transferable, then $\mathrm{Cr}$ and $\mathrm{Cd}$. Ni was not accumulated by the plants at all (at the present case).

At the present stage there is not enough knowledge concerning the mechanisms of metal tolerance and accumulation in the selected plant species. However, it can already be concluded from the results of both experiments, which were rather complementary than different, that $B$. napus could be good candidate for phytoremediation of contaminated areas.

\section{REFERENCES}

[1] Andreadakis, A.D., Mamais, D., Gavalaki, E., Kampylafka, S., 2002. Sludge Utilisation in Agriculture: Possibilities and Prospects in Greece, Wat.Sci.Tech., 46, (10), 231-238.

[2] Andreadakis, A.D. From the project "Hygienic management of sludge for agricultural utilization (SMAG), 1997-2001”.

[3] Bock, R., 1979. In: Marr, I. (Ed.), A Handbook of Decomposition Methods in Analytical Chemistry. International Textbook Co., Great Britain, pp. 201-222.

[4] 86/278/EEC. Council Directive of 12 June 1986 Concerning the protection of the environment, and in particular of the soil, when sewage sludge is used in agriculture.

[5] 91/271/EEC. Council Directive f 30 May 1991 concerning urban wastewater treatment.

[6] Cheng, H., Xu, W., Liu, J., Zhao, Q., He, Y., Chen, G., 2007. Application of composted sewage sludge (CSS) as a soil amendment for turfgrass growth. Ecol. Eng. 29, 96-104.

[7] Chaney, R., 1983. Fate of toxic substances in sludge applied to cropland. Proc. Int. Symp. Land Appl. of Sewage Sludge, 13-15. 
[8] Christoulas, G., Andreadakis, D., Kouzeli-Katsiri, A., Aftias, E., Mamais, D., 2000. Alternative schemes the management of the sludge produced at Psyttalia WWTP". Wat.Sci.Tech. 42, (9), 29-36.

[9] Environment Canada, 1985. L'epandage des eaux usees traitees et des boues d'epuration d'origine urbaine. Guide SPE 6-EP-84-1. Diraction Generale des programmes de protection de I'environment, 190.

[10] ISO 11465:1993. Soil quality-Determination of dry matter and water content on a mass basis-Gravimetric method.

[11] ISO 10390:2005. Soil quality-Determination of $\mathrm{pH}$.

[12] ISO 10694:1995. Soil quality-Determination of organic and total carbon after dry combustion (elementary analysis).

[13] Ivanova, V., Vassilev, A., 2002. Biometric and physiological characteristics of Chrysanthemum (Chrysanthemum Indicum L.) plants grown at different rates of Nitrogen fertilization. Journal of Central European Agriculture ISSN 1332-9049

[14] Katsoyiannis, A., Samara, C., 2004. Persistent organic pollutants (POPs) in the sewage treatment plant of Thessaloniki, northern Greece: occurrence and removal. Water Res. 38 (11), 2685-2698.

[15] Labrecque, M., Teodorescu, T.I., and Daigle, S., 1995. Effect of wastewater sludge on growth and heavy metal bioaccumulation of two Salix species. Plant Soil 171, 303-316.

[16] Mamais, D., Kouzeli-Katsiri, A., Christoulas, G., Andreadakis, D., Aftias, E., 2000. Evaluation of agricultural utilisation of the sludge produced at Psyttalia WWTP", Wat.Sci.Tech. 42, (9), 21-28.

[17] Manios, T., Stentiford, E., Millner, P., 2003. The effect of heavy metals accumulation on the chlorophyll concentration of Typha latifolia plants, growing in a substrate containing sewage sludge compost and watered with metaliferus water. Ecol. Eng. 20, 65-74.

[18] Matthews, P., 1999. A global atlas of wastewater sludge and biosolids use and disposal. Scientific and technical report No 4 - Vol. 197.

[19] McCutcheon, S., Schnoor, 2003. Phytoremediation. New Jersey, John Wiley\&Sons, pp. 19.

[20] Memon, A.R., Aktoprakligil, D., Ozdemir, A., 2001. Heavy metal accumulation and detoxification mechanisms in plants. Turk. J. Bot., 111-121.

[21] Miller, R.J., and Miller, J.N., 1986. Statistics for Analytical Chemistry. Ellis Horwood, Chichester. 
[22] Pulford, I.D., Watson, C., 2003. Phytoremediation of heavy metal-contaminated land by trees - a review. Environ. Int. 29, 529-540.

[23] Suchkova, N., Darakas, E., Ganoulis, J., 2010. Phytoremediation as a prospective method for rehabilitation of areas contaminated by long-term sewage sludge storage: A Ukrainian-Greek case study. Ecol. Eng. 36, 373-378.

[24] Tappero, R., Peltier, E., Grafe, M., 2007. Hyperaccumulator Alyssum murale relies on a different metal storage mechanism for cobalt than for nickel. New Phytologist $175,641-654$.

[25] Tsagarakis, K., 2007. Optimal number of energy generators for biogas utilization in wastewater treatment facility. En Con Man 48, 2694-2698.

[26] Vandecasteele, B., Samyn, J., Bruno De Vos, Muys, B., 2008. Effect of tree species choice and mineral capping in a woodland phytostabilization system: a case study for calcareous dredged sediment landfills with an oxidised topsoil. Ecol. Eng. 32, 263-273 